\title{
URBAN POLICY IN THE CONTEXT OF CONTEMPORARY URBANISATION PROCESSES AND DEVELOPMENT ISSUES OF POLISH CITIES
}

\author{
Jerzy J. PARYSEK \\ Adam Mickiewicz University, Institute of Socio-Economic Geography \\ and Spatial Management, Poznań, Poland
}

\begin{abstract}
The great dynamics and wide range of contemporary Polish processes of urbanisation as well as problems of city development and operation require setting objectives, formulating rules and implementing urban policy. Its aim should be to support municipalities in their attempt to solve primary problems. What makes such a policy necessary is the fact that, while cities play a crucial role in global socio-economic development, they also experience financial, demographic, social, environmental, housing and other problems most severely. Therefore in many cases cities cannot be generators of development and cannot be responsible for the implementation of the Lisbon Strategy, as stipulated by the European Union. The aim of this paper is to present the principles of urban policy which could be implemented in Poland taking into account both, the existing situation and the position of the European Union on this matter. It is assumed that urban policy will be implemented at two levels: supra-local (the European Union, state and regional) and local. The first of these levels will apply to all European cities, Polish cities and those of a particular region, while the other, to a particular city and its spatial components. The policy principles will result from EU documents for which urban policy is a component of regional policy. Primarily, it is the Leipzig Charter on Sustainable European Cities and the Green Paper on Territorial Cohesion: Turning territorial diversity into strength.
\end{abstract}

Key Words: urban policy, urbanisation, Polish cities

\section{Introduction}

In the new political situation present in Poland since 1990, especially after the restoration of a democratic system, local government and a market economy, the process of urban development has gained a new dimension. Particularly worth emphasizing is the reappearance, after 50 years of absence, of local government, a body responsible in law for securing the basic needs of a local community, the socio-economic development of a city, and its spatial development (Chojnicki, Czyż, Parysek, 1999). A consequence of these political changes was also Poland's opening to the world, which meant the country's fuller integration into ongoing processes, particularly globalisation. These changes have not only transformed its economic structures and boosted its socio-economic development, but have also stimulated such spatial processes as suburbanisation (and to a lesser extent reurbanisation). The new political conditions have also led to the emergence of new factors, but also new problems, of urban development (Parysek, 2005). The effect of development processes today is, on the one hand, a high dynamics of urban development, although mainly of urban agglomerations, and on the other, mounting problems to which city authorities have to find a solution, and this may not always be possible. Therefore, the resulting state of affairs makes it necessary to work out, 
bring into effect and consistently implement urban policy; a policy which would be a form of intervention of the public sector, or more precisely the state, regional and local authorities, in the ongoing processes and pre-formed situations.

Currently, an autonomous urban policy does not exist in Poland. If some form of urban policy is pursued, then it is a component of regional policy, which has taken on a real dimension and significance only after Poland's inclusion into the European Union structures in 2004 (Churski, 2007; Parysek, 2008). This means it is necessary to design and administer urban policy, which is usually understood as measures taken by authorities of various levels and connected with the planning and implementation of the socio-economic and spatial development of a city (Grochowski, 2005), or as the role of the city authority in managing urban development, following an evolution of the approach to governance (Swianiewicz, 2005). The aim of this paper is to outline an overall model of urban policy taking into account the experiences and guidelines of the European Union in this regard.

\section{Urban policy in the European Union}

It is difficult to clearly indicate the period when local, regional and national authorities began to implement what we understand today as urban policy. Measures adopted by planners to prevent chaotic urban development can be seen as elements of urban policy; they gained new significance in the late nineteenth century. It is possible to speak of the birth of an autonomous urban policy only in the 1980s. It was then, first in the U.S. and later in West European and other countries, that a series of measures were taken to overcome problems which big cities started to experience as a result of the crisis of the Fordist model of production and capital accumulation (Florida, Jonas, 1991; Newman, Ashton, 2004; Albrechts, 1992, 2004; Soja, 2002). Those activities can be treated today as the beginning of the work on and implementation of autonomous urban policy. The European Union as an association of countries began to develop its rules only in the early twenty-first century (meetings in Lille, Rotterdam and Bristol).

The basis for the urban policy formulated by the European Union (EU) was the awareness of the unique situation of modern cities, which play an important role in the development of the contemporary world as places of the concentration of the population, municipal infrastructure, property and businesses. In a sense, modern cities bear the responsibility for global development. At the same time they experience contemporary demographic, social, environmental, housing and other problems most acutely. Hence, cities cannot always be generators of socio-economic development, and thus become involved in implementing the key EU strategic document, namely the Lisbon Strategy. In this situation, what appears to be a priority for action is the working out of a multilevel urban policy which could be pursued in the European Union as a whole as well as in its individual Member States and their regions and cities. Every level of government - local, regional, national as well as European - would be responsible for formulating and implementing such a policy. The assumed urban policy hierarchy means developing appropriate urban policies at the above-mentioned levels of territorial organisation and coordinating them efficiently. In other words, what we need is an integrated urban policy, or generally speaking, an urban development policy (the Leipzig Charter, the Green Paper on Territorial Cohesion).

For these reasons, the European Union recommends drawing up and carrying out integrated urban development programmes. It suggests establishing partnerships between cities, especially in agglomeration and metropolitan areas, as well as between cities and rural areas. While leaving the Member States full freedom in implementing urban policies, the European 
Union recommends that they comply with the Leipzig Charter programme, stressing the crucial importance of a country's urban policy and its inspirational role for policies at lower levels. The EU also recognizes the need for European cities to build up cooperation on development policy and exchange experiences in this field.

According to the European Union documents, urban policy should seek two main objectives, namely: (1) adopting a model of integrated urban development policy which takes into account economic and social development, ecological issues and spatial development, and (2) devoting special attention to problem areas of cities. To achieve them, the main tasks and strategies of their implementation have been set (see Table 1).

\section{Guidelines for urban policy on the basis of the Leipzig Charter}

Table 1

\begin{tabular}{|l|l|l|}
\hline \multicolumn{1}{|c|}{ Aims } & \multicolumn{1}{|c|}{ Tasks } & \multicolumn{1}{c|}{ Strategies } \\
\hline $\begin{array}{l}\text { (1) Adopting a model of } \\
\text { integrated urban } \\
\text { development policy which } \\
\text { simultaneously takes into } \\
\text { account: economic, so- } \\
\text { cial, and spatial devel- } \\
\text { opment as well as ecologi- } \\
\text { cal issues }\end{array}$ & $\begin{array}{l}\text { - analysing factors and } \\
\text { constraints of development, } \\
\text { development plans, } \\
\text { - coordinating the spatial use } \\
\text { - coordination actions at the } \\
\text { local level (urban areas), and } \\
\text { engaging in the development } \\
\text { process of local businesses } \\
\text { and residents }\end{array}$ & $\begin{array}{l}\text { - creating high-quality public spaces, } \\
- \text { modernizing infrastructure networks } \\
\text { and improving energy efficiency, } \\
\text { innovation and qualified staff, as } \\
\text { factors of development. }\end{array}$ \\
\hline $\begin{array}{l}\text { (2) Devoting special atten- } \\
\text { tion to urban problem } \\
\text { areas }\end{array}$ & $\begin{array}{l}\text { - improving the quality of the physical } \\
\text { environment, } \\
\text { strengthening the local economy and } \\
\text { solving the problems of local labour } \\
\text { markets, } \\
\text { - pursuing an active education policy for } \\
\text { young people, } \\
\text { organizing efficient and affordable } \\
\text { public transport. }\end{array}$ \\
\hline
\end{tabular}

Source: own based on: LEIPZIGER CHARTER ON SUSTAINABLE EUROPEAN CITIES, 2007, European Commission, European Urban Knowledge Network.

It is also possible to discern certain principles of urban policy in the EU documents. They include: (1) recognizing national urban policy as the leading one (the national level), (2) pursuing urban policy as one of the uses of the EU structural funds, (3) using the funds to solve the main problems of city development and functioning, (4) drawing up integrated urban development programmes for the problems being solved, (5) considering the possibility of concrete cities participating in new EU initiatives concerning urban development, (6) understanding the importance of cities as generators of development and the need to solve their problems, and (7) recognizing the importance of exchanging experiences and increasing our knowledge of issues of sustainable urban development.

As a member of the European Union, Poland should join in the efforts to develop principles and directions of its own urban policy taking into account the EU guidelines in this field. The current situation of Polish cities and their many problems require new legal acts to be passed as soon as possible in order to allow urban policy to be implemented at all the levels of the state's territorial organisation. Such a policy is also necessary for efficient planning of the development of cities and urban agglomerations. 


\section{The development of Polish cities and the need for an urban policy}

As has already been stated, cities are both generators of development and places where many different problems accumulate. In addition, as places of concentration of socio-economic entities and municipal infrastructure, they serve adjacent areas. This means additional development and operation expenses that are not generated by city residents.

While the process of population concentration in cities, especially the largest ones, has slowed down in the recent years due to suburbanisation, the role of cities as areas of job concentration and service provision has not changed (Parysek, 2005; Parysek, Mierzejewska, 2005A, 2005B). Despite the gradual decline in the population, the role of cities in terms of housing concentration has not diminished either. For many people settling in a suburban area is not necessarily associated with leaving the previously occupied apartment in the city (acquiring a second place of residence); as for others, it means building a so-called 'summer house' for periodic use. This process, however, indicates the detachment of places of residence from a widely understood urban market (housing, jobs, services). On the one hand, this is due to growing individual motorisation, and on the other, to the adopted lifestyle and housing preferences connected with it, which change with the life cycle and with the improvement of one's financial situation (Hall, 2004).

Studies of the concentration of the population and fixed assets, housing, economic entities and schools indicate that the distribution of places of residence, work, and especially education is not clearly linked with that of the population (calculated for the set of the country's 16 regions, the correlation coefficients take the following values: 0.9895 for the population and housing distribution, 0.9374 for the population and economic entities, and 0.5429 for the population and post-primary students). Thus, the broadly understood municipal infrastructure does not only serve the inhabitants of cities, but also those who work and study there and take care of various businesses in a city while paying taxes in their places of residence.

It seems that this example indicates the need for the state to develop principles and provide financial support for cities (local urban policy) and to create conditions allowing cities to participate in the European Union structural funds.

At the same time, the pre-1990 neglect and deficiencies as well as certain consequences of the political transformation have given rise to the appearance of problem areas in Polish cities which require specific measures, including urban renewal. While one can hardly speak of shrinkage in the case of Polish cities, the process of depopulation of city centres, accompanied by the degradation of the building stock and infrastructure and not counteracted by reurbanisation processes, is increasingly apparent.

There is also no question that after 1989 the process of urbanisation in Poland took on a new character. The changes which have occurred in this respect are the result of dominant suburbanisation and not enough reurbanisation. This means that city authorities will be increasingly burdened with the costs of urban sprawl while the inflow of funds from taxpayers residing in the city will decline. The process of suburbanisation, which is the primary cause of the difficult situation of cities, has been well described, both in a European dimension (Berg, Drewett, Klassen, Rossi, Vijverberg, 1982) and a national one (Parysek, Mierzejewska, 2005; Parysek, 2008B, 2008C), and there is no need to describe it here. For the clarity of further exposition, however, it is essential at this point to state that: (1) As a result of suburbanisation, cities tend to spread (urban sprawl), and this fact should be taken into account when identifying 
and solving problems of urban development. This means that the basic research unit for the study of urbanisation processes is the agglomeration and not the city within its administrative boundaries (which of course does not mean a withdrawal from researching the city itself). (2) When working on the assumptions of the socio-economic development of a concrete city, the entire agglomeration must be taken into consideration as an area in which to balance the distribution of the population, jobs and service facilities, and in which to plan the development of physical infrastructure. (3) It should be borne in mind that a city is not a homogeneous whole and that problems which need to be solved may concern the entire city or its various parts. (4) Although the number of inhabitants, especially of large Polish cities, is declining, it is in fact primarily a shift of the place of residence (to a much lesser extent of jobs and public services) from a city to the area outside, which entails certain consequences. In many cases, this process can be treated as qualitative development of a city (urban infrastructure is extended and, theoretically, service as well as living conditions should improve). (5) Planning procedures, whether in socio-economic strategic planning or spatial planning, should include both the city (a unit of the territorial division of a country) and the agglomeration (a set of units of the territorial division of the country). (6) In the spatial planning of an agglomeration, the social costs of its spatial development and functioning should be taken into account, which means the possibility of a practical application of new ideas and models of spatial urban development, in full awareness of their strong and weak points. One can list here models of spatial order, which is assumed to be the main objective of spatial management (Sorenson, 1990, 1992; Parysek, 2003, 2006; Mierzejewska, 2003, 2009A), those of sustainable development (Mierzejewska, 2009A), smart growth, new urbanism, the MILU conception (Downs, 2001; Filion, 2000, 2003; Dale, 2003; Braun, 2006; Braun, Scott, 2004; Duany, Plater-Zyberk, Speck, 2001; Duany, Plater-Zyberk, Almina, 2003; Parysek, 2008C), the XXQ concept of cities (Nijkamp, 2008; Mierzejewska, 2009A), that of resurgent cities (Musterd, 2006; Storper, Manville, 2006; Cheshire, 2006), and other.

While all the above argues for the need to work out an urban policy in Poland for each level of the country's territorial organisation, it seems that the most important reasons in favour of this move are the real problems of Polish cities and the urban policy of the European Union, the foundations of which are presented in the afore-mentioned documents, i.e. the Leipzig Charter and the Green Paper, and which Poland as a member state is obliged to follow.

\section{Levels of urban policy}

Introduction. Urban policy, as previously stated, is basically a new phenomenon in Poland since it was never an autonomous task for authorities at various levels. Urban policy has gained a new meaning and dimension in contemporary times, especially after Poland's integration into the European Union. Certain elements of urban policy, including its directions, were included (1) at the national level: in strategies and plans of the country's socio-economic and spatial development, and most recently in the concept of spatial development policy, (2) at the regional level: in the strategies of a voivodeship's socio-economic development and plans of its spatial development, and (3) at the local level: in strategies of a city's socio-economic development and studies of the conditions and directions of its spatial development.

When taking into account the above-mentioned forms, urban policy in Poland has never been (1) autonomous, (2) pursued in an integrated manner, (3) systemic, carried out in a hierarchical system of units of the country's territorial division, (4) of high priority, and (which concerns not only Poland) (5) conducted in a supra-national dimension (according to the European Union guidelines, including the stipulations of the Leipzig Charter and the Green Paper on Territorial Cohesion: Turning territorial diversity into strength). 
Today, urban policy is a task which should be carried out in an integrated manner at all levels of the country's territorial division, especially national and local. At the national and regional levels (also at the level of the European Union) it will be an interurban policy, or simply an urban policy which should focus on a set of cities within a particular territory, while at the local level it will be an intraurban policy focusing on a concrete city. This kind of division can be seen in urban policies pursued in various countries around the world (Ley,1981, 1986, 1996; Martin, Mc Caan, Purcel, 2003; Newman, Ashton, 2004). Yet, in all of these cases, the effects of urban policy (in the full sense of the term) will always be felt in a particular city, primarily by the inhabitants, but also by economic entities.

However, it is the state's urban policy that should play a key role in the broadly understood urban policy which, as is stated in the Constitution of the Republic of Poland, is a common good of its entire population, including urban residents. This role of the state is specifically emphasised in the two European Union documents mentioned (the Leipzig Charter and the Green Paper).

Interurban policy. Urban policy at the central level (national urban policy). The origins of both urban policy and regional policy can be traced primarily to the uneven level of socio-economic development of cities. The disparities have been due to many different factors: geographical situation, natural conditions, historical past, spatial structure of cities, economic structure and level of its development, dominant functions, level of physical and social infrastructure, social cohesion, as well as human potential and its quality, adaptability to changing political, economic and social situations, various types of crises, and often various random factors. The varied influence of the above-mentioned factors and determinants has led to a situation in which some cities have to contend with a relatively large set of problems, while others cope quite well with difficulties related to functioning and development. The aim of the state's urban policy, like that of regional policy, ought to be to eliminate disparities in the level of socioeconomic urban development, and especially to improve residents' living conditions and quality of life, primarily by means of legal regulations and the financial support which it involves (Parysek, 2008A).

With Poland as a member of the European Union, its national urban policy should take into consideration the assumptions and guidelines of the EU urban policy, particularly those set in the Leipzig Charter and the Green Paper.

It appears that the primary task of the state is to determine general directions of urban policy, or an urban development strategy (within the national settlement system). In order to accomplish this task, there must be certain legal regulations which define the conditions and ways of solving problems connected with urban development and operation. Also, as has already been emphasised, it is necessary to provide financial support for implementing the objectives at the local level, i.e. in a concrete city, as that is where this policy will be implemented.

Perhaps the best legal regulation of the urban issue would be to pass a City Act which would determine the rules of city operation and the ways and means of solving urban problems. In this context, what seem to be urgently needed are legal regulations helping to prevent the degradation of the urban material substance (the building stock and infrastructure), inhibit spatial chaos (an urban renewal act and a new law on spatial planning), and stop the processes of social deprivation and exclusion. Legal regulations are also necessary to enable cities to (1) develop degraded areas, especially those owned by the State Treasury, (2) pursue 
rational real-estate management, (3) manage the housing stock rationally, (4) develop municipal construction, (5) maintain and expand urban roads, (6) develop urban infrastructure, (7) maintain objects of cultural heritage in good repair, (8) eliminate or at least reduce social polarisation, (9) develop culture and art, and (10) obtain financial support for solving the most pressing problems (material degradation and social deprivation, civilisational backwardness, etc.). The need for introducing legal regulations to solve problems of this kind has been indicated by politicians from many Polish cities (e.g. members of the Association of Polish Cities).

Urban policy at the regional level. The regional level of urban policy should primarily include the implementation of the state's urban policy in a given region. It should thus serve as a bridge between this policy and the local (internal) policy of each city. In this context, an important component of urban policy at the regional level should be defining the role of cities in the regional settlement system, in the implementation of the socio-economic development strategy of the region, and in the plan of its spatial development, and also determining ways to support urban development and solve the existing problems. This level of government also has the responsibility to reduce the disparities in the level of development of cities and in their residents' standards of living. Regional urban policy should pay special attention to the situation of the regional centre, primarily due to the fact that it is a generator of development throughout the region and a place of higher-order services for its residents. Urban policy at the regional level should eliminate the centre - rest-of-region antagonism. An important element of urban policy at the regional level should also be, it seems, taking into account the needs of cities when considering applications for European Union subsidies and the use of the EU Structural Funds.

Intraurban policy. Urban policy at the local level. The local level of government plays a special role in implementing urban policy. In fact, it is the basic and most important level of its implementation since it is here that the focus is finally on a concrete city and its problems. A city is also the place of integration of the urban policies of the European Union, the state, regional authorities and its own. Perhaps not so much of integration, but a transformation of interurban policies into an intraurban one. Finally, what seems to be most important is the fact that every city struggles with its individual problems which ought to be solved (Atkinson, 2000; Bourne, 1993; Friedrichs, 1993; Hamnet,1991; Sinclair, 1997; Sinclair, Thompson, 1976; Kowala-Stamm, 2006). If the assumptions and directions of intraurban policy are to produce specific results, they must be included in cities' strategies of socio-economic and spatial development. The objectives of intraurban policy are not only to ensure the socio-economic development of a city as a whole and to meet the collective needs of its people, but above all to solve its internal problems, which include such issues as various standards of living and different living conditions, various spatial accessibility of services, degradation of the building stock and infrastructure, underdevelopment of physical and social infrastructure, an unbalanced labour market, poverty and social pathologies, differences in ecological conditions, threat to human and property security, ethnic and racial issues (this basically does not apply to Polish cities yet), and other (Billert, 2006; Jędraszko, 2008; Mierzejewska, 2009B). Intraurban policy should also determine the general direction of a city's spatial development by earmarking investment areas and identifying preferences in the types of investment (a selective choice of investors), and contain a record of measures intended to result in the revitalisation of degraded areas. Thus, intraurban policy can be defined as the activity of local authorities carried out together with other city-based entities to ensure residents the best possible living conditions and opportunities of development.

Two basic dimensions of urban policy. Some authors draw attention to two distinct 
dimensions of urban policy, namely (1) political and (2) planning and decision-making (Grochowski, 2005). The political dimension means pursuing a policy which will gain the approval of city residents and allow the political party in power to keep governing the city. It is not difficult to note in this approach a client-patron view of governance, yet on the other hand it is difficult to question the point and meaning of a policy enjoying community support (Parysek, 1997). It is possible, at most, to discuss the relationship between authority and society (social satisfaction) and ask what is the cause and the effect in it. In turn, the planning and decision-making dimension of urban policy means taking measures which will (1) ensure further development of a city's economic base, (2) lead to its gaining a competitive advantage, (3) ensure residents the best services and the highest standards of living, (4) attract serious investors to the city, and (5) enhance its attractiveness and competitiveness as well as its importance as an economic, cultural and scientific-technological centre, gladly visited by customers and guests, and selected as a place to live and work in.

Of course, there must be a convergence between the political and the planning and decision-making dimensions of urban policy, which often involves the daunting issue of 'depoliticising' urban policy. This is important in the present times when the chief concern of political parties is maintaining power and fighting the political opponent. This may be the point of political activity, but such a perspective should be barred from urban policy because its objectives - the city's development and improving the living conditions and quality of life of its residents - require it to be a long-term and non-partisan process rather than one changing with the party in power. However, the fact that city (as well as regional and national) authorities engage more actively in development issues and making promises during pre-election periods clearly demonstrates that the political dimension of urban policy, dominates over the planning and decision-making one. It seems that no matter who holds power in a city, there should be a non-partisan climate in favour of its development and solving its problems. This is a task for both, regional and local authorities as well as local communities as bodies deciding about who is given power in their cities.

Socialisation of urban policy formulation. Formulating the directions of urban policy should be a social process at each level. This means that the directions of this policy should be arrived at by social consensus. At the local level this should be a consensus among residents, property owners, investors, and local authorities. There are many popular models of action which lead to achieving social consensus in both, planning and exercising power. In the case of planning, we have models of cooperation known as collaborative or cooperative planning (Healey, 1997, 1992; Alexander, 2002; Howe, Langdon, 2002). In the case of power, the idea is to pass from government to governance (Martin, Mc Cann, Purcell, 2003; Swianiewicz, 2005; Parysek, Toelle, 2007; Mierzejewska , 2009A).

Within each urban policy, it is necessary to develop effective tools of putting it into effect, especially when reality shows that many items in planning documents remain only a noble intention or a political slogan (Billert, 2006; Jedraszko, 2008). It is obvious that in developing such tools one must take into account, on the one hand, an academic point of view on socio-economic and spatial development of cities, and on the other hand, the point of view of the local community and its expectations. The latter, however, should take into account the existing reality, especially economic and financial. Obviously enough, no urban policy can be implemented without financial resources to back it up. 


\section{Conclusion}

At present, urban policy in Poland is not an independent field of actions seeking to eliminate differences in the level of socio-economic development among cities or to solve their problems, even though some elements of such a policy may be traced in strategic planning carried out at the central, regional and local levels. The European Union is keenly interested in the implementation of urban policy in its Member States, pointing to its multilevel nature (starting from the EU level, through the national and regional levels, and finishing at the local level). In the existing situation, national authorities face the task of defining the objectives, principles, ways of implementing and funding of their urban policies following the guidelines of the European Union. A special role in this regard is played by the urban policy of a state and local policies implemented by the authorities of every city. However, before an urban policy can be implemented, relevant legal regulations must be established, e.g. in the form of a city act. There is no question that at every decision-making level (EU, national, regional, local) urban policy should be an integrated one, combining environmental, social, economic and spatial issues. Of course, for urban policy to accomplish its objectives, appropriate financial resources have to be earmarked for it, independent of the possible means from the budgets of cities themselves or from the European Union funds. It is also clear that urban policy must combine the political dimension with the decision-making one, with a clear priority for the latter. In practice, this means 'de-politicisation' of urban policy, or giving it a non-partisan priority. The necessity of implementing urban policy results from the fact, emphasised in the European Union documents, that while contemporary cities bear a global responsibility for the socioeconomic development of the contemporary world as areas of concentration of the population, economic entities, municipal infrastructure and fixed assets, they also experience demographic, social, environmental, housing and other problems most acutely. In this situation cities cannot always be the generators of socio-economic development and thus become involved in implementing the Lisbon Strategy, especially after two years of a financial and economic crisis.

\section{References}

ALBRECHTS L. (1992), New challenges for urban policy under flexible regime of accumulation, Landsc. Urban Planning, 22, p.189-203.

ALBRECHTS L. (2004), Strategic (Spatial) Planning Reexamined, Environment and Planning, B 31, p.743-758.

ALEXANDER E. R. (2002), The Public Interest in Planning: form Legitimation to Substantive Plan Evaluation, Planning Theory 1/3, p.226-249.

ATKINSON R. (2000), Measuring Gentrification and Displacement in Greater London, Urban Studies, Vol. 37, No. 1, p.149-165.

BERG L. VAN DEN., DREWETT R., KLAASSEN L., ROSSI A., VIJERBERG C. (1982), Urban Europe: A Study of Growth and Decline, Oxford, Pergamon.

BILLERT A. (2006), Planowanie przestrzenne a polityka. Trzecia droga do trzeciego świata (W:) Urbanistyka w działaniu. Teoria i praktyka. Materiały II Kongresu Urbanistyki Polskiej (red. T. Ossowicz, T. Zipser), Biblioteka Urbanisty, 9, Warszawa, Urbanista, 2 .

BOURNE L. (1993), The myth and reality of gentrification: a commentary on emerging urban forms, Urban Studies, 30 (1) p.183-189.

BRADFORD N. (2004), Place matters and multi - level governance: Perspectives on a new urban policy paradigm, Policy Option, 25, 2.

BRAUN G. (2006), Smart growth. The end of a good idea; (W:) Cities in global perspective: Diversity and transition, (red. Y. Murayama, G. Du), Tokyo. Rikkyo University, p.79-93.

BRAUN G., SCOTT J. (2004), News from the urban front: dressing social innovation in urban and regional management, (W:) Cities in transition (red. M. Pak, D. Rebernik), 
Department of Geography, Faculty of Arts, Ljublana, University of Ljublana, Dela, 21 p.15-26.

CHESHIRE P. C. (2006), Resurgent cities, Urban myths and Policy hubris: What we need to know, Urban Studies, 43, 8, p.1231-1246.

CHOJNICKI Z., CZYŻ T., PARYSEK J. (1999), Transformation and dilemmas of the Polish economy, (W:) Shock - Shift in an enlarged Europe. The geography of socio-economic change in East - Central Europe after 1989 (ed. F.W. Carter, W. Maik), Aldershot, Ashgate, p.7 -26 .

CHURSKI P. (2007), Czynniki rozwoju regionalnego i polityka regionalna w Polsce w okresie integracji z Unią Europejską. Poznań, Wydawnictwo Naukowe Uniwersytetu im. A. Mickiewicza w Poznaniu.

DALE G C. (2003), Smart growth, Planning Commissioners Journal, 50, Spring

DOWNS A. (2001), What does smart growth really mean?, Plannig, 64, 4, p. 20-25.

DUANY A., PLATER - ZYBERK E, ALMINANA R. (2003), The new civic art: Element soft town planning, New York. Rizzoli Publ.

DUANY A., PLATER - ZYBERK E., SPECK J. (2001), Suburban nation: The rise and the decline of the American dream, North Point Press.

FILION E. (2000), Balancing concentration and dispersion? Public policy and urban structure in Toronto, Environment and Planning, C. 18, p.163-189.

FILION P. (2003), Towards smart growth. The difficult implementation of alternatives to urban dispersion, Canadian Journal of Urban Research, 12, 1, Summer, p. 48-60.

FLORIDA R., JONAS A. (1991), U.S. Urban policy: The postwar state and capitalist regulation, Antipode, 23, 4, p.349-384.

FRIEDRICHS J, (1993), A theory of urban decline, Urban Studies, 30, 6, p.907 - 917.

GREEN PAPER ON TERRITORIAL COHESION (2008), European commission, DG Regional Policy, Brussels.

GROCHOWSKI M. (2005), Polityka miejska a kształtowanie struktury przestrzennej miasta metropolitalnego (przypadek Warszawy). Warszawa. Uniwersytet Warszawski. Prace $i$ Studia Geograficzne.

HALL P. (2004), Whose habitable city?. The resurgent City. Leverhulme International Symposium 2004, London, London School of Economics, Symposium Papers.

HAMNETT C. (1991), The blind men and residential location theory: A review and assessment. (W:) Geography and the urban environment, Progress in research and application (red. D.T. Herbert, R.J. Johnston), London, Wiley \& Sons.

HEALEY P. (1997), Collaborative planning: Shaping places in fragmented societies, London, Macmillan.

HEALEY P. (1992), Planning through debate. The communicative turn to planning theory, Town Planning Review, 63 (2), p.143-162.

HOWE J, LANGDON C. (2002), Towards a Reflexive Planning Theory, Planning Theory, 1/3, p. 209-225.

JĘDRASZKO A. (2008), Gospodarka przestrzenna w Polsce wobec standardów europejskich, Biblioteka Urbanisty, 13, Warszawa, Urbanista.

KOWALA - STAMM K. (2006), Destrukcja miasta i znaczenie inicjatyw społecznych dla konsolidacji kwartałów śródmiejskich na przykładzie Detroit, Przegląd Geograficzny, 78, 4, p.537-560.

LEIPZIGER CHARTER ON SUSTAINABLE EUROPEAN CITIES (2007), European Commission, European Urban Knowledge Network.

LEY D. (1981), Inner city revitalisation in Canada: A Vancouver case study, Canadian Geographers, 2, p.124-148.

LEY D. (1986), Alternative explanations for inner-city gentrification, Annals of the Association of American Geographers, 4, p.521-534.

LEY D. (1996), The New Middle Class and the Remaking of the Central City, Oxford, 
Oxford University Press.

MARTIN D., MC. CANN E., PURCELL M. (2003), Space, scale, governance and representation: Contemporary geographical perspectives on urban politics and policy, Journal of Urban Affairs, 25, 2, p.113-121.

MIERZEJEWSKA L. (2003), Rozwój zrównoważony, jako kategoria ładu przestrzennego. (W:) Społeczno - gospodarcze i przyrodnicze aspekty ładu przestrzennego (red. T. Ślęzak, Z. Zioło) Biuletyn Komitetu Przestrzennego Zagospodarowania Kraju PAN, 205, p.127-140.

MIERZEJEWSKA L. (2009A), Rozwój zrównoważony miasta: Aspekty poznawcze i praktyczne. Poznań, Wydawnictwo Uniwersytetu im. A. Mickiewicza w Poznaniu.

MIERZEJEWSKA L. (2009B), Urban planning in Poland in the context of European standards, (W:) Urban and regional development and planning (red. J. Parysek), Quaestiones Geographicae. 28B (w druku).

MUSTERD S. (2006), Segregation, urban space and resurgent city, Urban Studies, 43 , 8, p.1325-1340.

NEWMAN K., ASHTON P. (2004), Neoliberal urban policy and new path of neighborhood change in the American inner city, Environment and Planning A. 36, p.11511172.

NIJKAMP P.(2008), XXQ factors for sustainable urban development: A systemic economics view, Romanian Journal of Regional Science, 2, 1, p.2-34.

PARYSEK J. (2003), Ład przestrzenny jako kategoria pojęciowa i planistyczna, (W:) Społeczno - gospodarcze i przyrodnicze aspekty ładu przestrzennego (red. T. Ślęzak, Z. Zioło) Biuletyn Komitetu Przestrzennego Zagospodarowania Kraju PAN. 205, p.111-126.

PARYSEK J. (2005), Development of Polish cities and factors affecting this process at the turn of the century, Geographia Polonica, 78,1.

PARYSEK J. (2006), Wprowadzenie do gospodarki przestrzennej, Poznań, Wydawnictwo Naukowe Uniwersytetu im. A. Mickiewicza w Poznaniu.

PARYSEK J. (2008A), Polityka regionalna i planowanie regionalne w Polsce (W:) O nowy kształt badań regionalnych w geografii i gospodarce przestrzennej (red. T. Stryjakiewicz, T. Czyż). Biuletyn KPZK 237, p.9-35.

PARYSEK J. (2008B), Aglomeracje miejskie w Polsce problemy ich funkcjonowania (W:) Wybrane problemy rozwoju i rewitalizacji miast: aspekty poznawcze i praktyczne (red. J. Parysek, A. Toelle). Biuletyn Instytutu Geografii Społeczno - Ekonomicznej i Gospodarki Przestrzennej Uniwersytetu im. A. Mickiewicza w Poznaniu. Seria. Rozwój regionalny i polityka regionalna 5 , p.29-48.

PARYSEK J. (2008C), Urbanizacja i niektóre współczesne idee, koncepcje i modele planowania rozwoju miast (W:) Współczesne kierunki i wymiary procesów urbanizacji (red. J. Słodczyk, M. Śmigielska), Opole, Uniwersytet Opolski, p.11-26.

PARYSEK J., MIERZEJEWSKA L. (2005 A), Między dezurbanizacją a reurbanizacją: Nowe oblicze urbanizacji w Polsce (red. I. Jażdzewska), Łódź, Wydawnictwo Uniwersytetu Łódzkiego, p. 47-56.

PARYSEK J., MIERZEJEWSKA L. (2005 B), Two stages in postwar urbanisation in Poland: From socialist to postmodern urbanisation (W:) Cities in global perspective: Diversity and transition (red. Y. Murayama, G. Du), Tokyo, Rikkyo University, p. 72 - 82.

PARYSEK J., TOELLE A. (red.) (2007), Urban development and urban governance. Quaestiones Geographicae, 26 B, Wydawnictwo Naukowe Uniwersytetetu iom., A. Mickiewicza w Poznaniu, Poznań.

SINCLAIR R. (1997), The changing context of racial segregation: an examination in metropolitan Detroit, Geographia Polonica, 69, p. 153-166.

SINCLAIR R., THOMPSON B. (1976), Detroit. An Anatomy of Social Change, Cambridge, (Massachussetts), Ballinger Publishing Company. 
Jerzy J. PARYSEK

SOJA E. W. (2000), Postmetropolis. Critical studies of cities and regions, London, Blackwell.

STORPER M., MANVILLE M. (2006), Behaviour, preferences and cities: Urban theory and urban resurgence, Urban Studies, 43, 8, p. 1247-1274.

SWIANIEWICZ P. (2005), Nowe interpretacje teoretyczne polityki miejskiej. Studia Regionalne i Lokalne, 4 (22), p. 5-25.

TOWARDS BALANCED AND SUSTAINABLE DEVELOPMENT OF THE TERRITORY OF THE EUROPEAN UNION (1999), Commission of the European Communities, Luxembourg, http://ec.europa.eu/ egional_policy/sources/docoffic/ official/reports/pdf/sum_en.pdf.

Received at : 8.11.2010

Revised at: 11.12.2010

Accepted for publication at: 20.12 .2010 